\title{
TECTONOPHYSICS
}

\section{Forearc-basin closure and arc accretion in the submarine suture zone south of Taiwan}

\author{
Neil Lundberg a,, , Donald L. Reed ${ }^{\mathrm{b}}$, Char-Shine Liu ${ }^{\mathrm{c}}$, Jay Lieske, Jr. ${ }^{\mathrm{d}}$ \\ a Department of Geology, Florida State University, Tallahassee, FL 32306, USA \\ ${ }^{b}$ San Jose State University, San Jose, CA 95192, USA \\ ' Institute of Oceanography, National Taiwan University, Taipei, Taiwan \\ ${ }^{d}$ Department of Geology and Geophysics, Princeton University, Princeton, NJ 08544, USA
}

Received 21 February 1996; accepted 8 August 1996

\begin{abstract}
The obliquely propagating Taiwan collision provides an active example of an intraoceanic arc being accreted to a young rifted continental margin. The actual accretion of the exotic arc is taking place immediately south of Taiwan, in a complex area of rapid uplift and shortening between the emerging crest of the submarine accretionary prism and the extinct northernmost segment of the Luzon volcanic arc. The northern part of this region accommodates over half of the convergence between the Philippine Sea and Eurasian plates, based on recent results of triangulation and Global Positioning System studies. Assuming that nearly all the plate convergence to the south, in the region of normal intraoceanic subduction, is concentrated near the active trench, as is true in most subduction zones, this region of arc accretion is a zone across which approximately $60 \%$ of the total plate convergence, amounting to about $50 \mathrm{~mm} / \mathrm{yr}$, is being actively transferred. This transfer of slip is presumably caused by the buoyant nature of continental crust that has been subducting beneath the Taiwan orogen. This arcward transfer of plate convergence has strongly affected development of the suture between the Luzon arc and the continental margin, represented by the Taiwan mountain belt.

Backthrusting of the accretionary prism in this region is accommodated on east-vergent thrust faults, which locally reach the surface and deform the entire forearc sequences, thereby building the Huatung Ridge, a distinct structural and bathymetric ridge east of the main accretionary prism (the Hengchun Ridge). The Huatung Ridge dams orogenic sediment from the emergent collision in the Southern Longitudinal Trough, a suture basin that projects directly northward to the Longitudinal Valley of eastern Taiwan. Growth strata in the Southern Longitudinal Trough document progressive uplift of the Huatung Ridge to the east, apparently along east-verging thrust systems.

Seismic reflection and sidescan sonar data south of about $23^{\circ} \mathrm{N}$ provide no evidence of back-arc thrusting along the eastern margin of the Luzon arc, as has been hypothesized in order to transfer shortening to the Philippine Sea plate. Neither do these data show clear evidence of west-vergent thrusting of the Luzon arc over adjacent elements of the forearc, in contrast to the very active thrusting documented onland to the north, along the Longitudinal Valley of eastern Taiwan.

The arcward-vergent structures in the region of arc accretion have closed the North Luzon Trough, the major forearc basin. These structures have also built the Huatung Ridge as a compressional ridge of orogenic strata that serves to broaden the accretionary prism toward the arc (eastward) and, in so doing, have formed small collisional or suture basins and redirected orogenic sedimentation patterns throughout this key area. Thus the arcward flank of the collision has evolved in a much more complicated fashion than the relatively smooth progression followed by the western, frontal slope of the
\end{abstract}

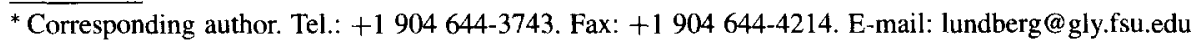


submarine accretionary prism as it evolves northward to the fold-and-thrust belt exposed along strike in western Taiwan. This complexity on the arcward flank of the collision zone is likely a response of the collision complex to continued plate convergence in the face of increasing resistance, to the north, to the subduction of continental crust.

Keywords: collision; plate convergence; two-sided orogens; accretionary prisms

\section{Introduction}

Investigations of modern arc-continent collisions along continental margins provide valuable insights into orogenic processes and continental growth, and provide an active example for the evolution of complex, resource-rich continental margins characterized by accreted terranes. The active Taiwan collision provides a relatively simple collision between a rifted continental margin and an overriding island arc that is propagating along strike (Fig. 1). This collision is oblique and is propagating southward, as the Luzon arc, developed along the leading edge of the Philippine Sea plate, accretes to the underthrusting but buoyant continental margin, closing the intervening South China Sea progressively from the north.

The oblique nature of this collision, controlled by a $50^{\circ}$ angle between the Asian passive continental margin and the intraoceanic Luzon arc (Suppe. 1984) provides the opportunity to investigate different stages of collision by comparing along-strike variations within the collision zone. One of the most complicated, and least well understood, segments of this developing collision is that immediately south of eastern Taiwan. In this region, major fault systems accommodate a large portion of the overall plate convergence between the Philippine Sea and Eurasian plates and close the fundamental suture between arc and continental crust in this system.

To the south of the developing collision, south of about $20^{\circ} \mathrm{N}$, oceanic crust of the South China Sea is subducted beneath the Philippine Sea along the Manila Trench. This intraoceanic convergence, along an azimuth of $307^{\circ}$ (Yu and Chen, 1994), is oriented at a moderately oblique $\left(40^{\circ}\right)$ angle to the plate boundary. To the north, the island of Taiwan exposes a young and active mountain belt that makes up the mature arc-continent collision. The Central Mountains of Taiwan emerge from beneath the sea as an enlarged accretionary prism, built mainly of thick Eocene to Miocene continental-rise and -slope deposits of the passive continental margin. deformed and metamorphosed as they encounter the Manila Trench subduction zone (Suppe, 1987). A wide variety of onland studies have established significant constraints on the structural geometry. metamorphism and thermal framework, uplift history, and tectonic evolution of the collision. Far less is known about the critical region just south of Taiwan, through which normal intraoceanic subduction evolves into the active suture belt. This paper reports on marine investigations of the transition zone between subduction and collision immediately south of Taiwan, in order to outline the principal tectonic processes and structural mechanisms operating during the early stages of collision development. We also compare these marine observations to studies of the onland suture exposed in eastern Taiwan in order to evaluate evidence for the progressive development of the present suture.

\section{Region of arc accretion}

The critical region through which the Luzon arc is incorporated into the Taiwan collisional mountain belt is shown in Fig. 2. The Luzon arc is represented in this area by Lutao and Lanhsu Islands, volcanoes that erupted as recently as 0.5 m.y. and 1.4 m.y. ago, respectively, and by a young volcanic islet just south of Lanhsu (Hsiaolanhsu), which has yielded fissiontrack ages as young as 0.02 m.y. (Yang, 1995). To the south along the arc lie the active volcanoes of the Batan Islands, and to the north are accreted arc rocks that form the basement of the Coastal Range of eastern Taiwan. These intermediate-composition volcanic rocks, agglomerates, and tuff, known as the Chimei Igneous Complex and the Tuluanshan Formation, represent arc igneous activity that had begun by at least $16 \mathrm{Ma}$; most volcanism ended by about 5 m.y., with local eruptions to about 2.2 m.y. (Lo et al.. 1994; Yang, 1995). 


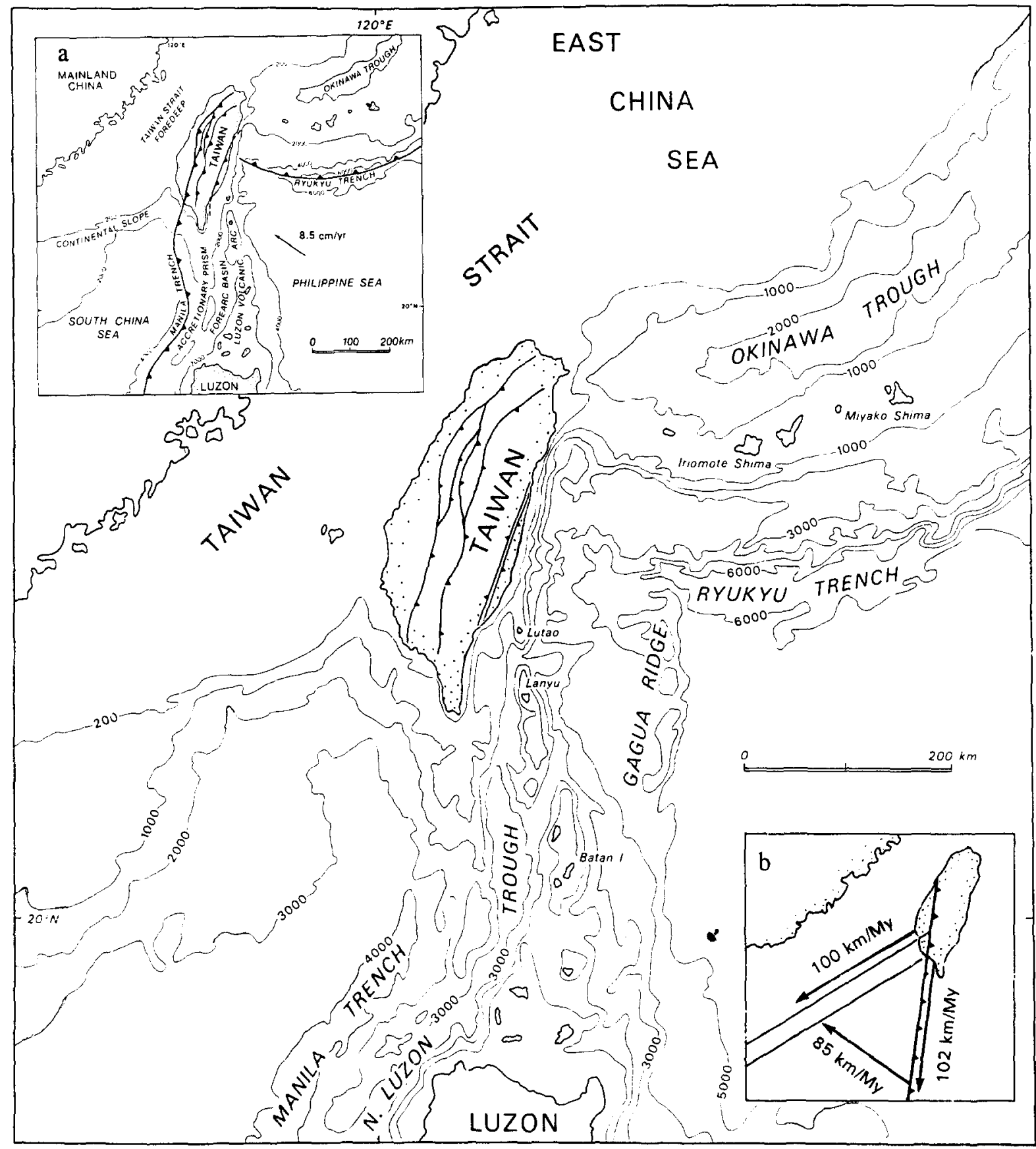

Fig. 1. Tectonic setting of the Taiwan arc-continent collision. Inset a: plate boundaries near Taiwan. Note that polarity of subduction flips at the Taiwan collision; submarine accretionary prism expands northward to become the $\sim 4-\mathrm{km}$-high mountain range of Taiwan. Inset b: velocity triangle for the arc-continent collision: convergence at $85 \mathrm{~km} / \mathrm{m}$.y. drives the collision $100 \mathrm{~km} / \mathrm{m}$.y. along the Chinese margin, propagating the collision zone $102 \mathrm{~km} / \mathrm{m}$.y. south along the Luzon arc and Manila Trench. Modified from Suppe (1984) and Dorsey (1988), based on convergence velocity by Yu and Chen (1994). 


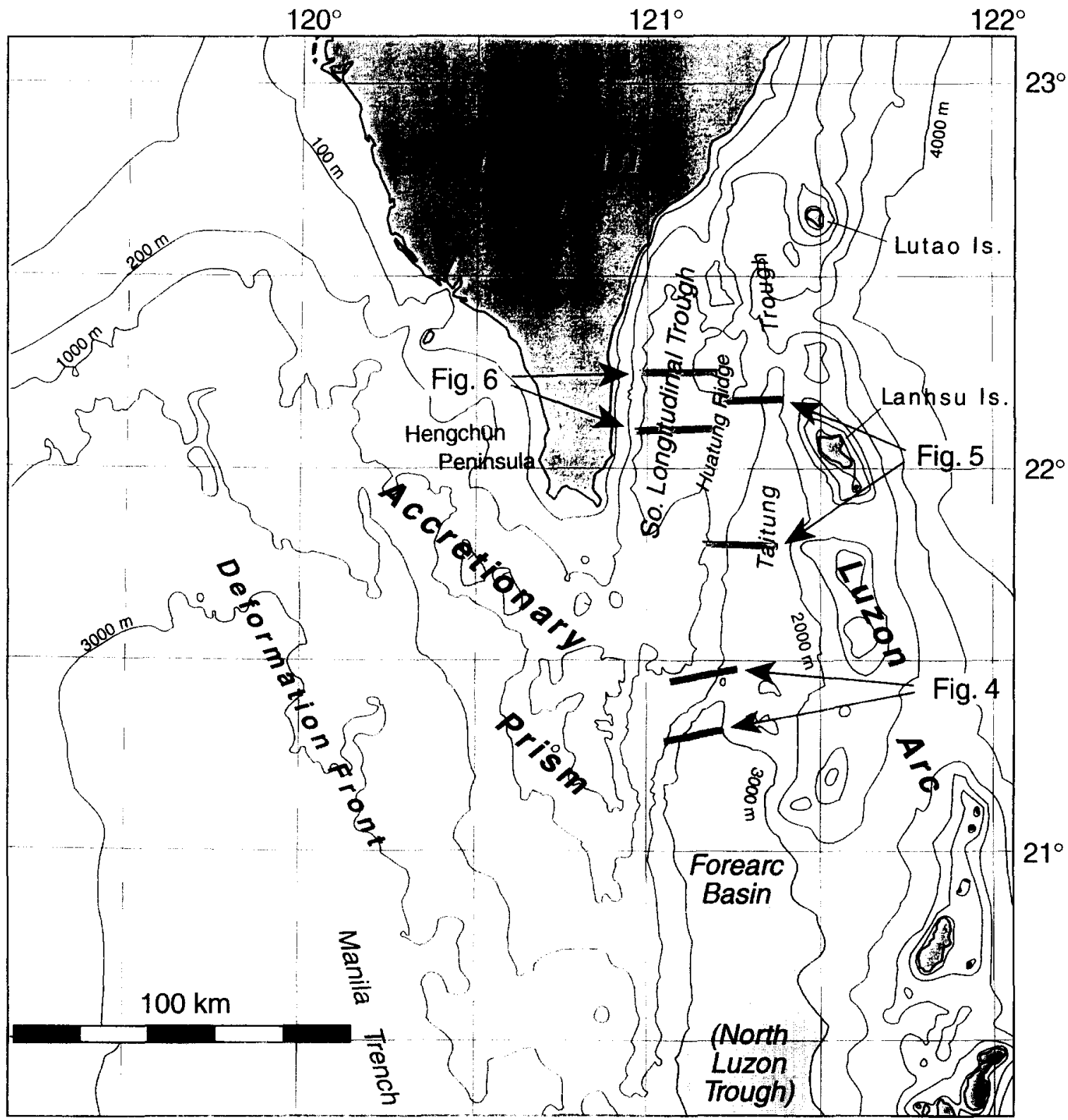

Fig. 2. Regional map of the southern Taiwan oftshore areal, depicting bathymetric and tectonic leatures referred to in text and locations of seismic reflection profiles presented in following figures.

Between the Luzon arc and the Manila Trench, the crest of the submarine accretionary prism rises northward to emerge as the Hengchun Peninsula, which in turn gives way toward the north to the Central Mountains of Taiwan (Fig. 2). The region of arc accretion is one of elongate submarine ridges and irregular intervening basins and canyons, with a major submarine ridge, the Huatung Ridge, between the Hengchun Peninsula and the main arc edifice (Fig. 2). The Huatung Ridge projects northward directly to the Coastal Range of eastern Taiwan, and separates the Southern Longitudinal Trough from the Taitung Trough (Chen et al., 1992). The Southern Longitudinal Trough is a perched, shallow basin. 
whereas the Taitung Trough is a composite feature, comprising a narrow, steep-sided submarine canyon over part of its length, opening to the south to a small, irregularly shaped basinal area (Fig. 3; Lundberg et al., 1992; Huang et al., 1992). The northern, canyon-like segment of the Taitung Trough empties laterally eastward through a narrow canyon between Lutao and Lanhsu Islands to the Philippine Sea (Lundberg, 1988).

To the south of the region of active arc accretion, the forearc domain between Luzon and Taiwan, bounded by the Manila Trench on the west and the Luzon arc to the east, is about $150 \mathrm{~km}$ wide, with the arc itself spanning another $50 \mathrm{~km}$ or so (Fig. 1). The accretionary prism in this region, called the North Luzon Ridge in the south and the Hengchun Ridge to the north, thickens eastward, with its surface rising from about 4000 to $4500 \mathrm{~m}$ deep along the Manila Trench, where it overlies Tertiary oceanic crust of the South China Sea, to a crest that typically reaches depths as shallow as about $2000 \mathrm{~m}$. Between the accretionary prism and the Luzon arc, a well defined forearc basin, the North Luzon Trough, comprises a deep $(\sim 3600 \mathrm{~m})$ and elongate depocenter with a generally flat floor that dips very gently southward toward Luzon (Lewis and Hayes, 1984). Basin fill in the forearc basin ranges up to $4 \mathrm{~s}$ (two-way travel time) thick, but is generally less than $1 \mathrm{~s}$, about $1 \mathrm{~km}$ thick, assuming a sediment velocity of about $2 \mathrm{~km} / \mathrm{s}$.

Northward toward Taiwan, the distance between the accretionary prism and the arc narrows dramatically. To the south, at latitude $21^{\circ} \mathrm{N}$, the distance from the steep eastern slope of the accretionary prism to the steep eastern slope of the arc edifice is about $110 \mathrm{~km}$; the analogous distance across eastern Taiwan, from the steep eastern slope of the Central Mountains to the steep eastern slope of the accreted arc, is about $50 \mathrm{~km}$ at latitude $23^{\circ} \mathrm{N}$, and only $30 \mathrm{~km}$ at $24^{\circ} \mathrm{N}$ (Fig. 1; Lundberg and Dorsey, 1988). This is clearly a region of strong net east-west horizontal crustal shortening, and we infer that a similar tectonic domain has accommodated considerable shortening as the collision has evolved, comprising the southward propagating tip of the collision. Over this same segment of the collision, the submarine accretionary prism grows in both width and height toward the north, as it encounters the continental margin with its thick sedimentary sequence and overlying thick collision-derived clastic wedge. The width of the submarine accretionary prism, measured from trench to the forearc basin, grows northward from about $95 \mathrm{~km}$, south of the collision at $20^{\circ} 30^{\prime} \mathrm{N}$, to about $170 \mathrm{~km}$ across the southern tip of Taiwan at $22^{\circ} \mathrm{N}$. The northward broadening of the accretionary prism and the northward narrowing of the forearc basin are related, in part. Although much of the northward growth of the prism is due to frontal offscraping and accretion of thick sedimentary sequences along its western deformation front, some of this growth results from the incorporation of deformed forearc-basin strata into the rear, arcward flank of the prism, as arc crust is underthrust westward below the accretionary prism.

\section{Closure of the forearc basin and formation of the Huatung Ridge}

In the region south of eastern Taiwan, backthrusting along the rear (arcward) slope of the accretionary prism structurally closes the main forearc basin, the North Luzon Trough, producing the shallower, relatively narrow Taitung Trough (Fig. 4; Lundberg et al., 1992; Reed et al., 1992). Forearc-basin strata remain remarkably undeformed across and along most of the North Luzon Trough, except along the western margin of the basin, where they are tilted systematically eastward to form the lower portion of the arcward slope of the accretionary prism. Backthrusting is blind along the western margin of the North Luzon Trough, and may form a tectonic wedge (or "triangle zone;' Lundberg et al., 1992; Lieske et al., 1992).

Bathymetrically, the arcward slope of the accretionary prism (western margin of the North Luzon Trough) comprises a remarkably linear north-south feature, a steep slope with 2000-3000 m of relief, which trends due north toward the similarly steep eastern slope of the Central Mountains of Taiwan (Lundberg et al., 1992), with one notable exception. At $21^{\circ} 10^{\prime} \mathrm{N}$, the northernmost point at which the forearc basin retains its depth of approximately $3600 \mathrm{~m}$, the arcward slope of the accretionary prism veers distinctly northeast for about $30 \mathrm{~km}$, to about $21^{\circ} 20^{\prime} \mathrm{N}$ (Figs. 2 and 3). This NE-trending segment of the east-facing prism slope, formed as the accretionary prism is thrust relatively farther eastward over the Luzon arc, effectively widens the accre- 


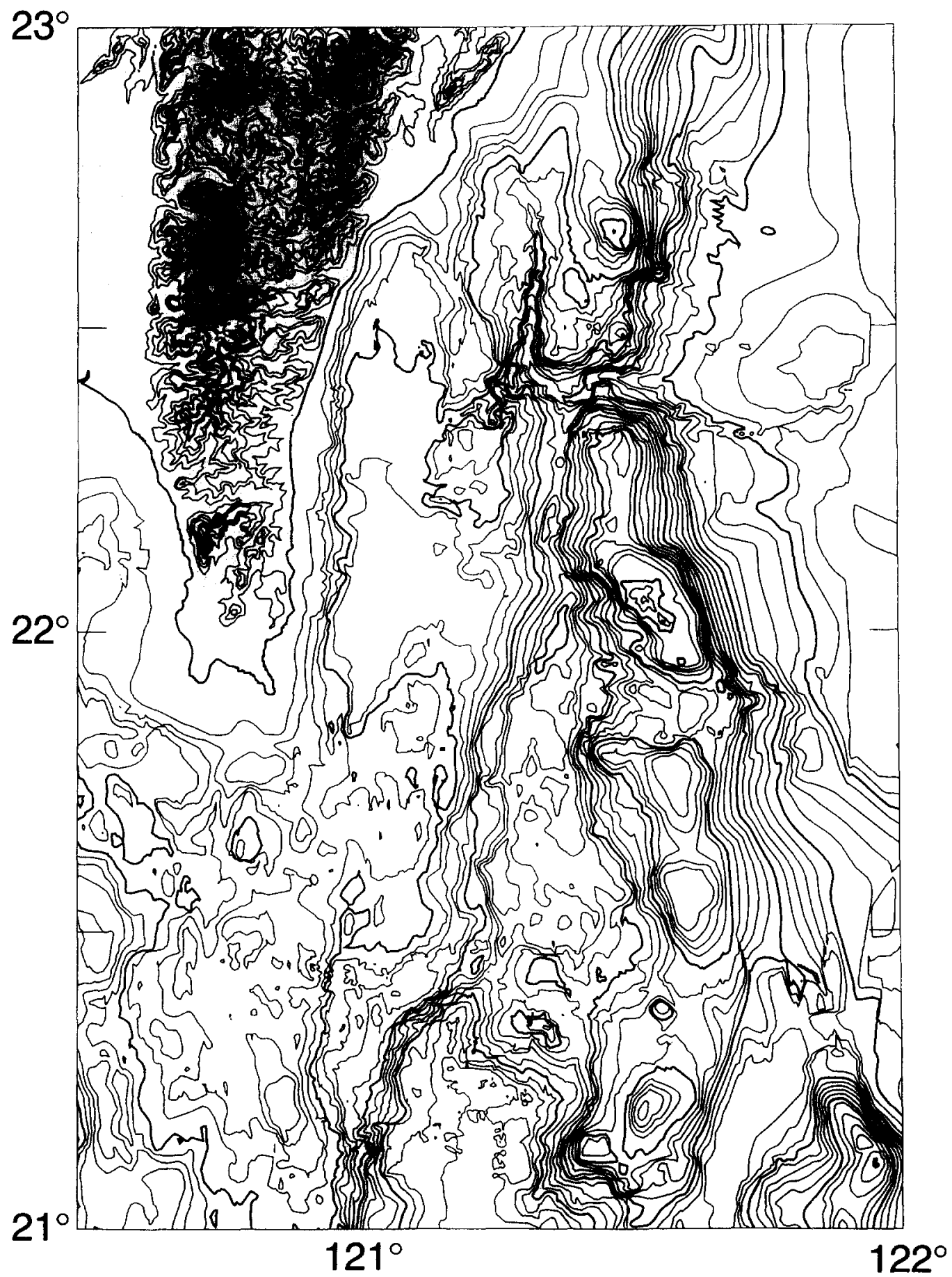

Fig. 3. Bathymetry of the region of forearc-basin closure and arc accretion off southeast Taiwan (hand-contoured, based on SeaMARC II swath bathymetry). Contour interval: $100 \mathrm{~m}$, bold contours: $1000 \mathrm{~m}$. 
tionary prism considerably toward the east, with consequent narrowing of the distance between the accretionary prism and the arc. Northward, toward the developing collision, this NE-trending, E-vergent deformation front curves to trend northward, about $30 \mathrm{~km}$ eastward of the northward extension of the steep eastern slope of the accretionary prism to the south. Thrusting along this deformation front has uplifted a structural and bathymetric ridge, the Huatung Ridge, which extends northward directly toward the Coastal Range of eastern Taiwan (Fig. 2).

Just north of the North Luzon Trough, sonar images and bathymetry reveal two small basins between the arc and accretionary prism. These basins are not as deep as the North Luzon Trough, with a maximum depth of $\sim 2600 \mathrm{~m}$ (Fig. 3). The northern basin is filled with 1 to $2 \mathrm{~s}$ of layered sedimentary material on top of generally west-dipping volcanic basement. Unlike the North Luzon Trough, in which deformation is restricted to the basin margin adjacent to the accretionary prism, deformation in these basins involves the entire basin fill. Likewise, in contrast to the blind backthrusting inferred along the arcward slope of the accretionary prism to the south, eastvergent thrusts along the base of the eastern slope of the Huatung Ridge reach the seafloor (Fig. 5). Much of the Huatung Ridge is composed of folded and faulted strata that apparently accumulated in the forearc basin, prior to its structural closure, and in the smaller depocenters that have formed between the accretionary prism and the arc following closure of the North Luzon Trough.

The base of the eastern slope of the Huatung Ridge, in particular, consists of gently folded, reflective strata, clearly representing, at least in part, former strata of the western portions of these basins that have been deformed by east-vergent thrusting (Fig. 5). These deformed forearc strata overlie westdipping arc crust that is actively underthrusting the collision complex toward the west. Although the upper sediment surface of the basin is horizontal, there is a syncline at depth whose axis lies at or near the base of the eastern slope of the Huatung Ridge; basinal strata generally dip westward, whereas the slope strata dip eastward. Because the entire fill of the basin is involved in the deformation, a fault must pass along the sediment-basement contact or through the basement.

\section{Southern Longitudinal Trough}

Immediately east of the Hengchun Peninsula, the southern tip of Taiwan, a linear basin has formed behind (westward of) the structural sill provided by the Huatung Ridge. This basin, named the Southern Longitudinal Trough by Chen et al. (1992), projects northward directly to the Longitudinal Valley of eastern Taiwan (Fig. 3). The offshore basin and the onshore valley are remarkably similar in present-day morphology as well as in their tectonic setting, suggesting that they both represent a single fundamental structural boundary that survives well into the mature stage of arc-continent collision. This depocenter represents a modern suture basin, formed over the developing suture between the accreting Luzon arc and the deformed continental-margin units represented by the Central Mountains of Taiwan.

The present depositional surface of the Southern Longitudinal Trough is essentially flat-lying along an east-west direction, and slopes gently southward from about 800 to $1200 \mathrm{~m}$. At its southern terminus, basinal strata become progressively deformed by the structures that form and deform the Huatung Ridge. Small slope channels provide detritus from the west, from small rivers along the eastern slope of the southern Central Mountains (exposing the Slate Formation, comprising deformed mid-Tertiary deposits of the Asian slope and rise) and the Hengchun Peninsula. The Southern Longitudinal Trough is full of orogenic sediment, unlike the North Luzon Trough (forearc basin), with the spill point located mid-way along the north-south Huatung Ridge (Fig. 3).

Much of the Southern Longitudinal Trough is filled by growth strata, which record relative uplift of the Huatung Ridge, which forms the sill of this basin (Fig. 6). Growth strata along the eastern margin of this basin are especially clear. Uppermost strata are nearly flat-lying, but with depth the strata dip increasingly more steeply toward the west, documenting progressive tilting inferred to result from uplift of the Huatung Ridge along an underlying east-vergent thrust system. Arc crust is underthrusting this basin from the east, below the deformed forearc-and collisional-basin strata that forms the Huatung Ridge. Deformed rocks of the subjacent terrane to the west may also be structurally encroaching on the basinal 


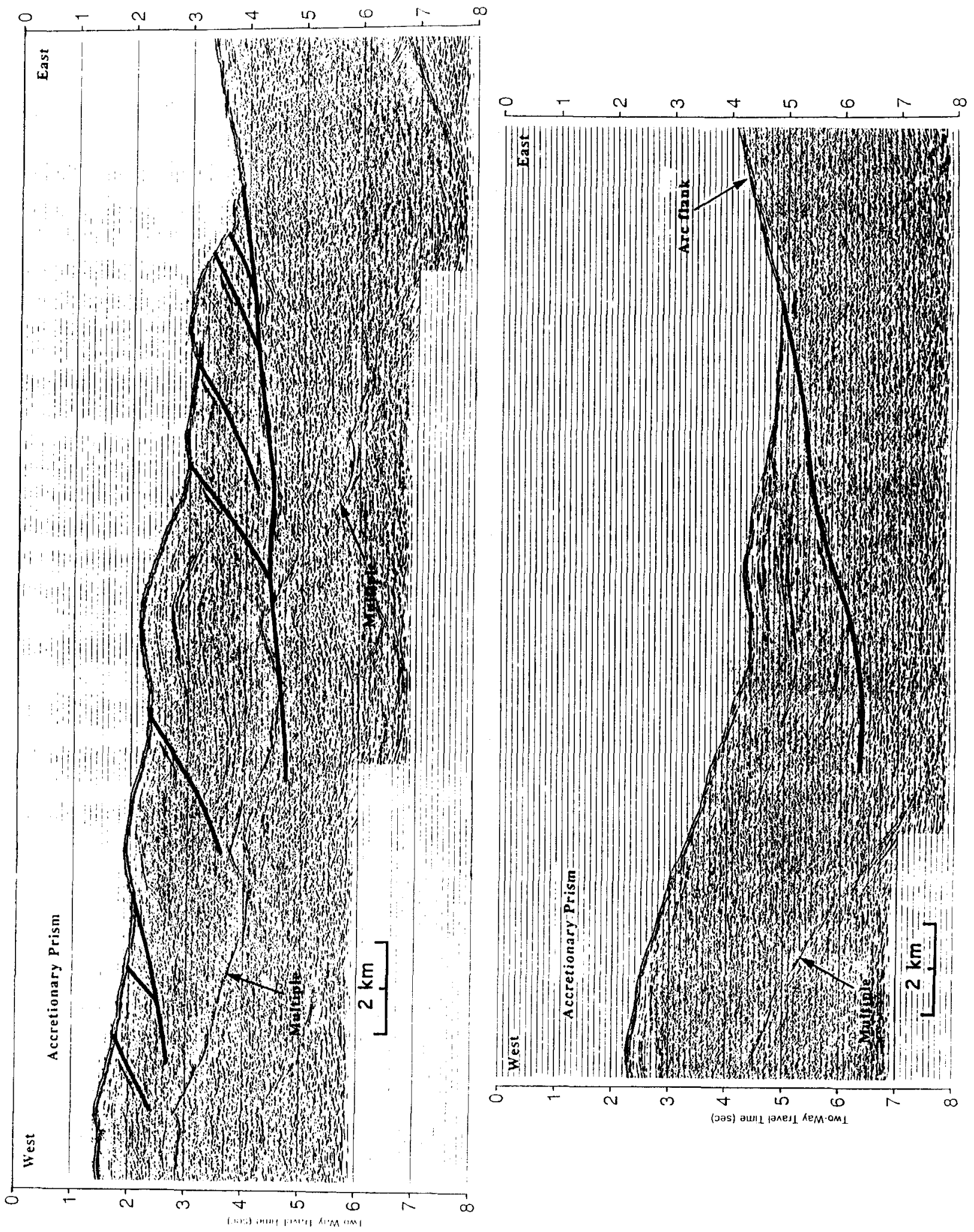


strata from the east, although this region is not well imaged by our seismic data.

A canyon immediately east of the Huatung Ridge, named the Taitung Trough by Chen et al. (1992), is actually a composite morphologic feature. In the north it is a steep canyon, sloping southward, but this canyon meets a northward-sloping canyon head-on, and the confluence then runs eastward through a narrow pass cut between Lutao and Lanhsu Islands, meandering to the back-arc region of the west Philippine Sea (Fig. 3). The southern portion of the 'Taitung Trough', south of Lanhsu Island, comprises the deeper portions of the small collisional basins north of the North Luzon Trough.

\section{Constraints on deformation of the Luzon arc}

We have not imaged clear evidence of thrusting of the main edifice of the Luzon arc offshore, by either seismic reflection data or by SeaMARC II sidescan sonar imagery. In particular, we observe no evidence of back-arc thrusting, as documented in other systems and as predicted by Suppe (1981), among others, in this system. It is perhaps not surprising that we observe no seismic reflection evidence of thrusting or folding in the arc massif, considering the difficulties in imaging through volcanic rock, but such structures could possibly be imaged, if present, in the volcaniclastic sediment apron present in a number of regions off Taiwan. Back-arc thrusting would be more likely to be imaged by sidescan sonar, however, in the form of lineaments, as are many thrusts in the frontal portion of the accretionary prism; we observe no evidence of such thrusts along the eastern margin of the Luzon arc.

\section{Comparison with onland geology of eastern Taiwan}

Dominance of eastward thrusting of the submarine accretionary prism over west-vergent thrusting of the Luzon arc, throughout the transitional zone between normal intraoceanic subduction to the south and collision to the north, is in direct contrast to neotectonic relationships documented onland in eastern Taiwan, along the Longitudinal Valley. The Longitudinal Valley is a remarkably linear, fault-bounded valley that reaches only about $200 \mathrm{~m}$ elevation, but which extends over $120 \mathrm{~km}$ NNE along eastern Taiwan (e.g., Lundberg and Dorsey, 1990). Along its entire length, this valley separates the accreted island arc terrane, with its superjacent sedimentary cover of forearc-basin and collisional-basin strata, from deformed, deep-level rocks of the Central Mountains that represent the deformed continental margin. The Longitudinal Valley is likely underlain by ancient forearc-basin strata, deformed but stratigraphically overlying arc basement (Lundberg and Dorsey, 1988).

Geodetic surveys across the Longitudinal Valley show that the western margin of the accreting arc is actively overthrusting the valley floor, representing the onland remnant of the forearc basin, at extraordinary rates of up to 2 to $3+\mathrm{cm} / \mathrm{yr}$ of both shortening and uplift (Yu and Liu, 1989; Liu and Yu, 1990). Thrusting with the opposite vergence has long been hypothesized along the other side of the Longitudinal Valley, along the eastern margin of the Central Mountains (Lundberg and Dorsey, 1988; and many others). This is not occurring at present, however, if indeed it ever has. Recent GPS results show minor extension, rather than shortening, across the southern Central Mountains (Yu and Chen, 1994), and structural analysis by Crespi et al. (1996) has revealed evidence of normal faulting extending along the length of the Central Mountains.

The accreted arc terrane that makes up the Coastal Range of eastern Taiwan has experienced very rapid uplift and denudation, at rates at least comparable to those of the rest of Taiwan. Onland studies have suggested uplift and erosion of sequences at least 6 to 7 $\mathrm{km}$ thick in less than 1 million years, and conceivably in substantially less time (Lundberg and Dorsey, 1990). Geodetic surveys combined with tide-gauge

Fig. 4. Migrated 4-fold seismic reflection profiles along arcward margin of submarine Taiwan accretionary prism, showing backthrusts that close forearc basin. (a) Portion of line MW9006-16, showing imbricate thrust system deforming strata deposited in forearc basin, over decollement developed over arc basement. (b) Portion of line MW9006-18, located approximately $15 \mathrm{~km}$ south of line 16, showing gentle anticline developed at base of steep arcward slope of submarine Taiwan accretionary prism. See Fig. 2 for locations. 

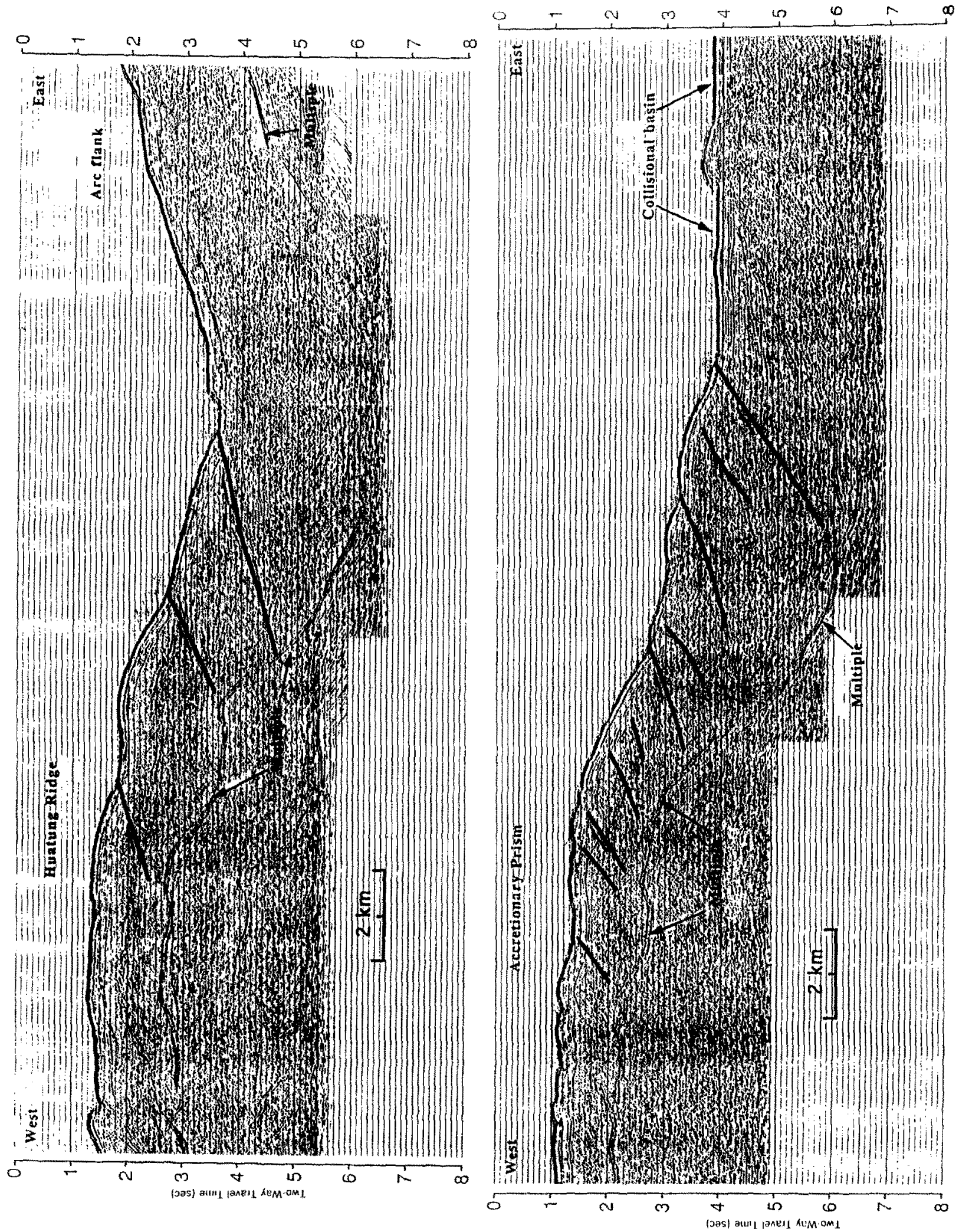
data have also documented uplift of the accreting arc terrane at rates of up to $35 \mathrm{~mm} / \mathrm{yr}$ in one location, with uplift remarkably consistent over time, based on repeated measurements over $4+$ years (Yu and $\mathrm{Liu}$, 1989; Liu and Yu, 1990).

Judging from the nature of the rocks exposed in the Coastal Range, the Huatung Ridge, which is the analogous feature offshore to the south, likely incorporates arc rocks on which forearc strata were deposited. Further, these strata likely include chaotic olistostromal deposits that have been deformed into melange, similar to the Lichi Melange, which outcrops across the southern terminus of the Coastal Range. The origin of the Lichi Melange remains controversial. Parts of this chaotic unit are demonstrably interbedded with coherently bedded strata, however, and part of the mixing of blocks of diverse lithologies is clearly due to surficial processes (e.g., Page and Suppe, 1981). At the same time, parts of the Lichi Melange exhibit tectonized fabrics, and many exposures show it to be clearly in fault contact with adjacent units. Although it has been interpreted by some workers as a fault-generated, or even subduction-generated, melange, it can most simply be interpreted as of dominantly olistostromal origin, although it has been tectonized, at least locally producing a fabric of slickensided blocks in a scaly claystone matrix.

\section{Accommodation and transfer of plate convergence}

New Global Positioning System (GPS) measurements, collected over four years, suggest that overall convergence across the Taiwan collision is actually slightly faster (by 15-20\%) than that predicted by the NUVEL-1 model (Seno et al., 1993), at $86.3 \pm 2.4$ $\mathrm{mm} / \mathrm{yr}$ along $307^{\circ}$, measured over a span of 223 km (Fig. 7; Yu and Chen, 1994). Less than half of this convergence is accommodated by the foreland fold-and-thrust belt ( 37 to $41 \mathrm{~mm} / \mathrm{yr}$ ), of which, in turn, about half is across a single near-frontal thrust fault. Small extensional strains of 5 to $9 \mathrm{~mm} / \mathrm{yr}$ were measured across the southern Central Mountains; but the largest portion of the plate convergence, $52 \mathrm{~mm} / \mathrm{yr}$, is accommodated between the eastward (arcward) flank of the Central Mountains and Lutao and Lanhsu Islands, the arc volcanoes on the leading edge of the Philippine Sea plate (Fig. 7; Yu and Chen, 1994). Shortening across the very active Longitudinal Valley of eastern Taiwan, which represents the onland trace of the arc-continent suture, accounts for about $60 \%$ of this 'hinterland' portion of the plate convergence, with the remainder accommodated between the southeast coast of Taiwan and Lutao and Lanhsu Islands. The GPS results across the Longitudinal Valley fault system are corroborated by trilateration-survey data (Yu et al., 1992). Thus over half of the considerable plate convergence is accommodated through the region of arc accretion.

Northward along the Longitudinal Valley, aseismic slip gives way to high seismicity, including thrust (Wu et al., 1989) and possibly also strikeslip earthquakes (Bonilla, 1975). Left-lateral slip observed following earthquakes in the northern Longitudinal Valley (Hsu, 1962) and left-lateral strike-slip earthquakes reported east and southeast of Taiwan (Pezzopane and Wesnousky, 1989; Lewis and Hayes, 1989) suggest that oblique plate motion may be decoupled in some regions, into a system of strike-slip faults and margin-parallel thrust fault systems (Reed et al., 1992). Seismic travel-time residuals analyzed by Roecker et al. (1987) and more recently by Rau and $\mathrm{Wu}(1995)$ indicate that continental crust now extends beneath virtually the entire island of Taiwan.

It is not clear just how slip is transferred from an inferred locus near the Manila Trench, well to the south of Taiwan, as is typical of the strain distribution at modern subduction zones, across the accretionary prism to the arcward flank of the collision in southeasternmost Taiwan. The simplest explanation would be strike-slip faults south of Taiwan, right-lat-

Fig. 5. Migrated 4-fold seismic reflection profiles along arcward margin of Huatung Ridge off southeast Taiwan, showing backthrust system inferred to form this ridge. (a) Portion of line MW9006-30, showing imbricate thrust system deforming strata deposited in forearc and collisional basins, over underthrusting volcanic/volcaniclastic basement of (extinct) Luzon arc. (b) Portion of line MW9006-25, located approximately $15 \mathrm{~km}$ south of line 30 , showing small collisional basin developed between submarine Taiwan accretionary prism and accreting Luzon arc (basement of collisional basin). See Fig. 2 for locations. 


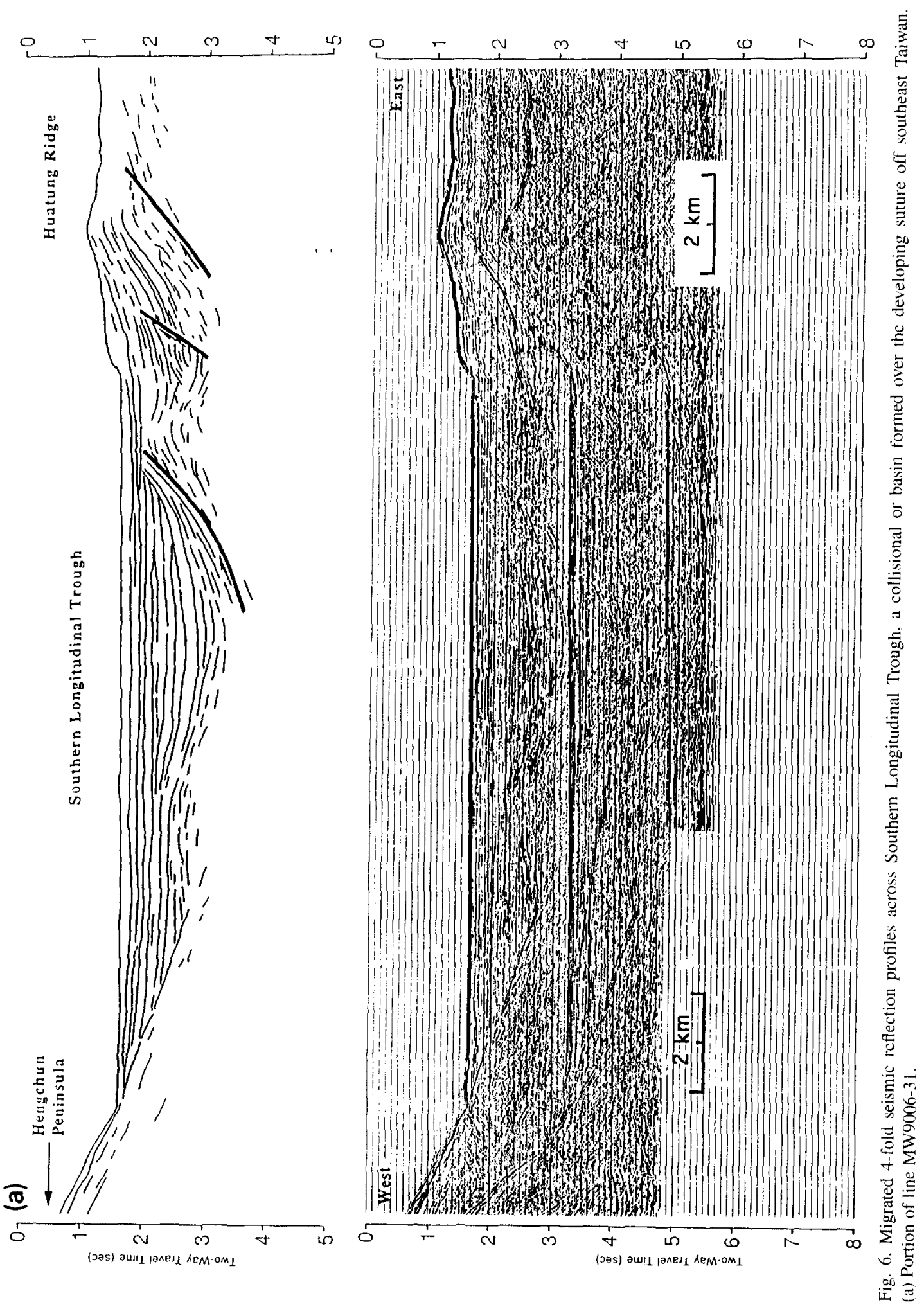



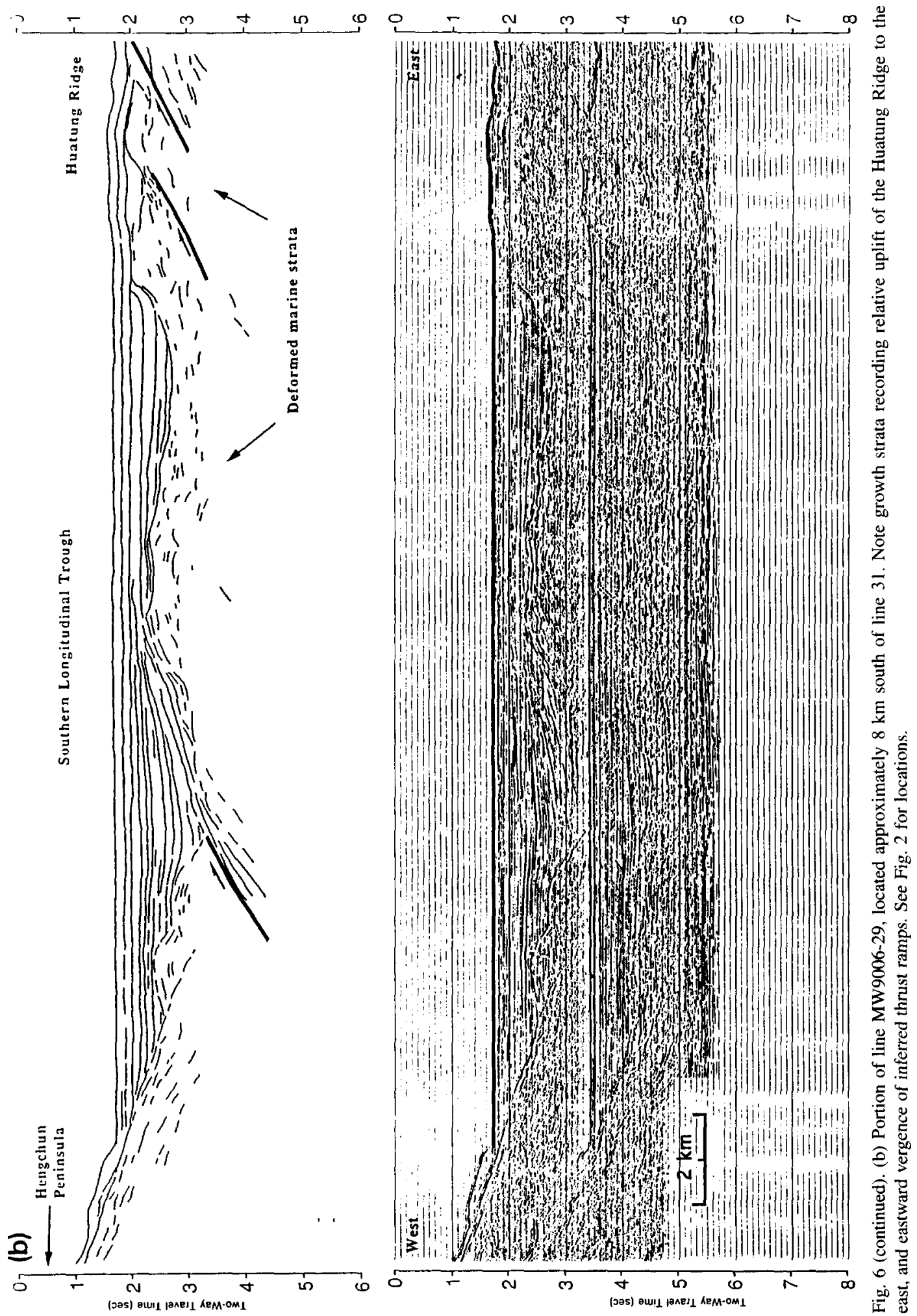


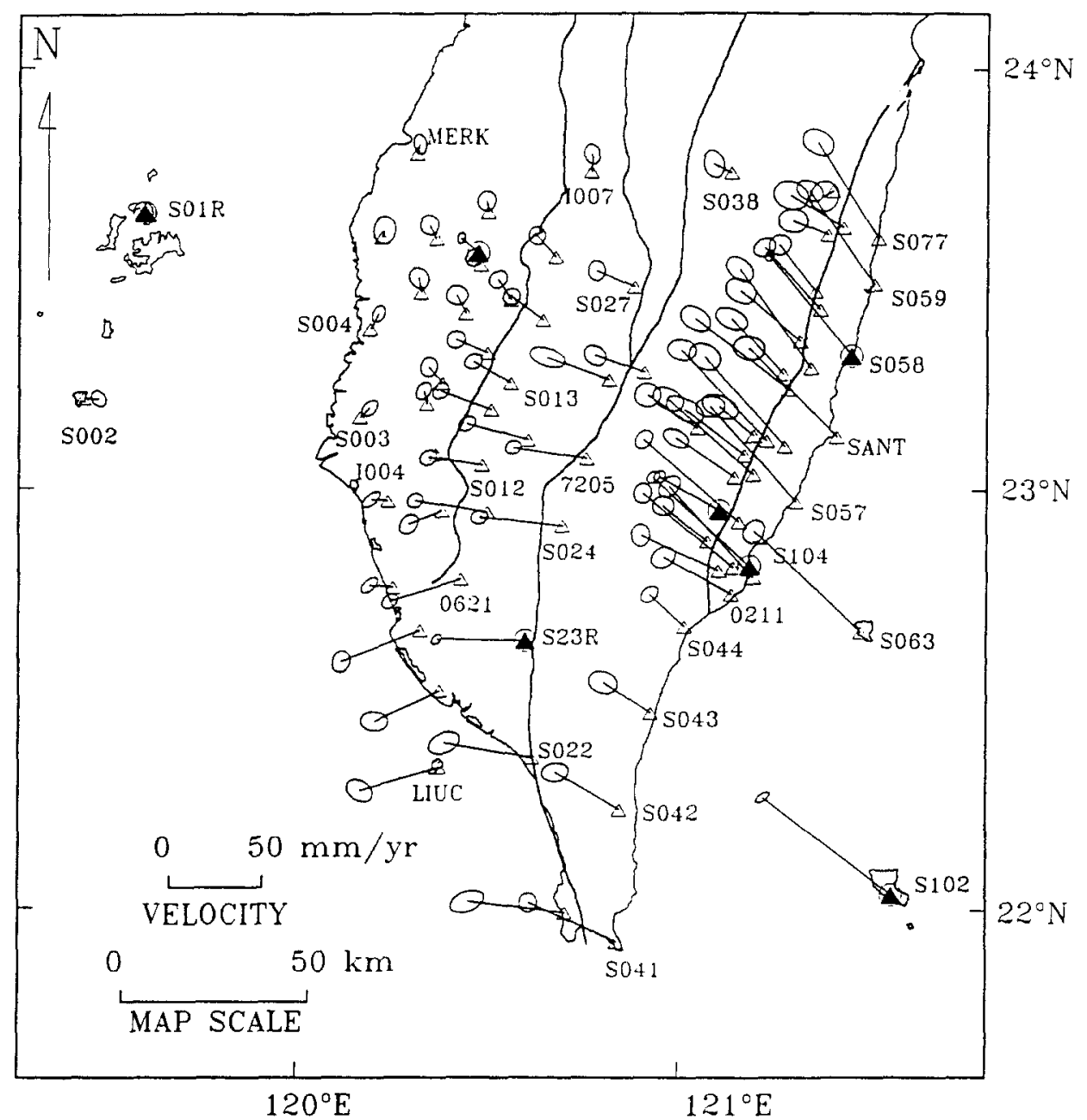

Fig. 7. Map showing present-day horizontal motions in the southern Taiwan region, relative to a nearby point on the Eurasian plate (Paisha. labeled S01R), based on Global Positional System measurements: from Yu and Chen (1994). Velocity vectors extend from stations (triangles), with 95\% confidence ellipses shown at vector tips. Note that over half of the plate convergence between the Philippine Sea and Eurasian plates is actually accommodated across the eastern portion of the collision here in the south, between the Hengchun Peninsula (southernmost Taiwan) and the northern islands of the Luzon are (labeled S063 and S102). Assuming that most convergence to the south is accommodated near the Manila Trench, as in most subduction zones, over half of this convergence is transferred to the rear of the accretionary prism by the collisional stage represented by the emergent elements exposed on southern Taiwan.

eral tear faults that would provide an accommodation structure allowing the bulk of the accretionary prism to the south to move west relative to the Central Mountains. Sidescan mosaics show candidate lineaments, but most trend NE-SW (Fig. 8a; see Fuh et al., 1997). Strike-slip faults of an accommodation zone should trend parallel to the plate convergence, or about $307^{\circ}$ (Yu and Chen, 1994), roughly $90^{\circ}$ to most candidate faults; so this seems not to be the case. On the other hand, active faults extend south- ward offshore from all along the southern shore of Taiwan, from the foreland of western Taiwan to the Longitudinal Valley. It is possible that slip along orogen-parallel faults is transferred gradually arcward, from the frontal portion of the accretionary prism, well south of Taiwan, gradually toward the arcward flank of the prism near southern Taiwan (Fig. 8b).

One reason that an accommodation zone may not be well developed here is that the arcward transfer of slip is likely a very young feature of the collision, at 


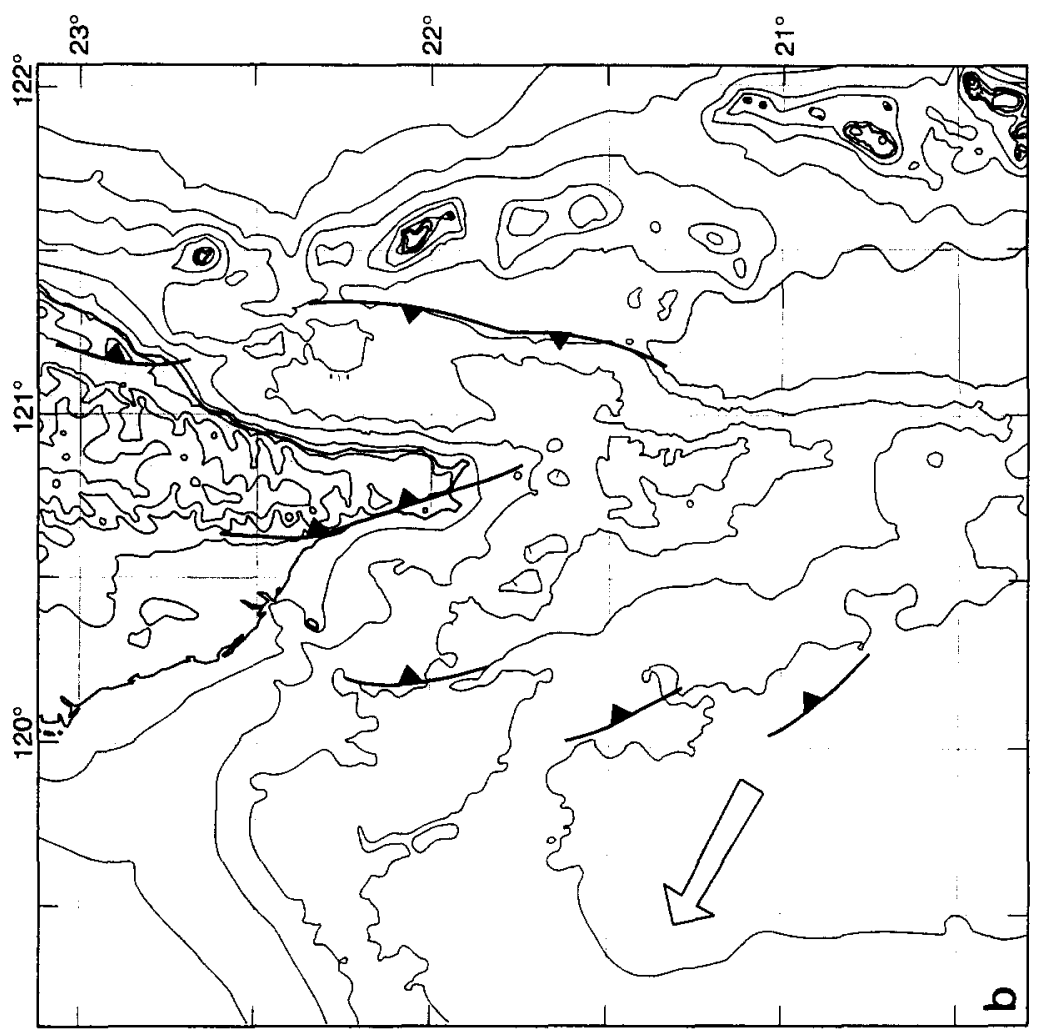

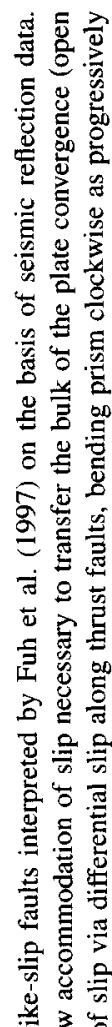

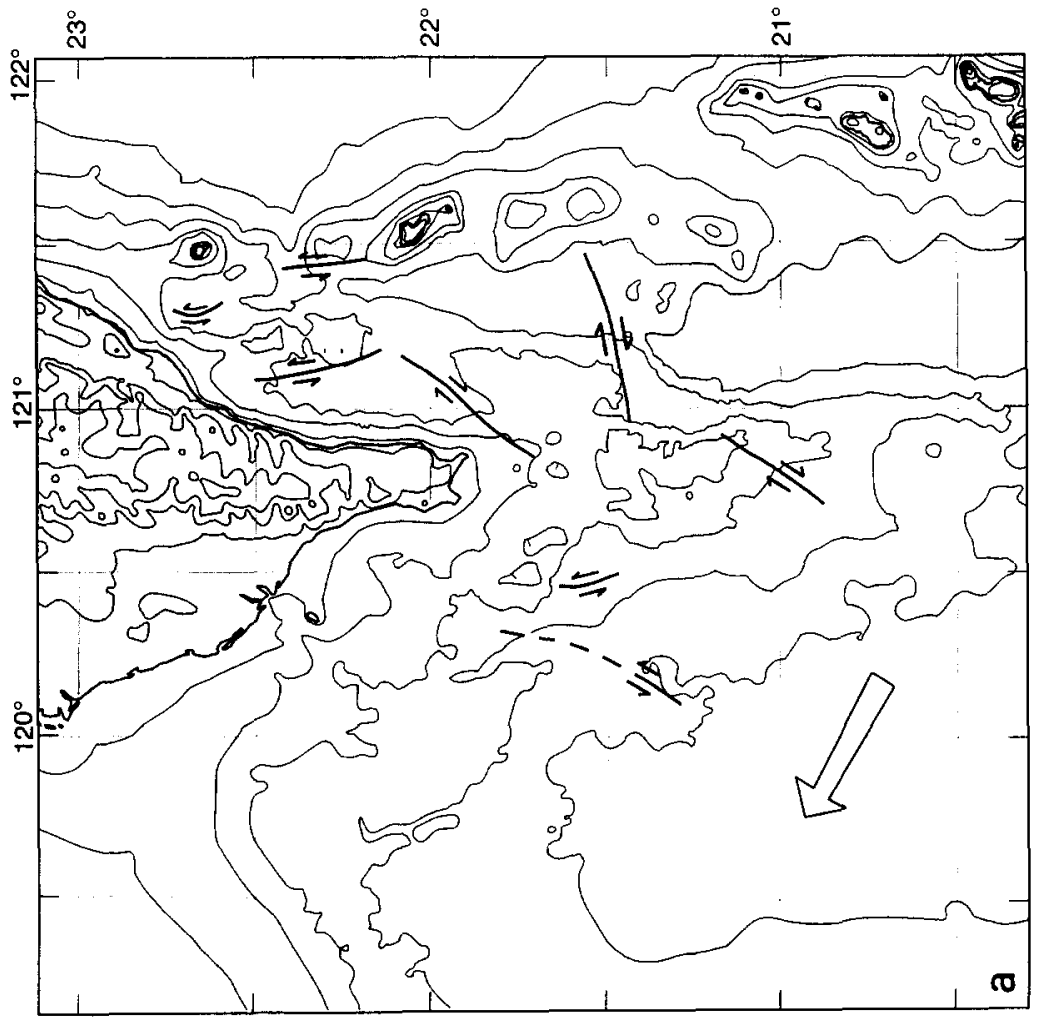

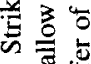

త)

ธ용

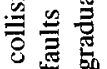

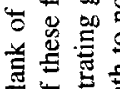

焉焉

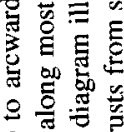

角鲜参

t०

远

总密它

要

跣记

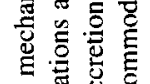

늘

氛 
least at the present rate; there may not have been sufficient cumulative slip over a sufficiently long period of time to produce obvious structures. Based on the clearest manifestation of this slip transfer, the dritmatic westward thrusting of the accreted arc along the Longitudinal Valley, the present maximum uplift rate of $3.5 \mathrm{~cm} / \mathrm{yr}$ (Liu and Yu, 1990) could not have been operating continuously for more than about 0.2 m.y., or deeper-level rocks would be exposed in the hanging wall of the thrust. Although deformation apparently related to arc accretion has affected the Coastal Range for several million years (Lee et al. 1991; Huang et al., 1992), this deformation probably operated at lower rates than at present. Total plate convergence over $0.2 \mathrm{~m} . \mathrm{y}$. would amount to only about $20 \mathrm{~km}$, translating to an estimated arcward transfer of on the order of $10 \mathrm{~km}$ at present high rates, potentially distributed over an arc-trench span of over $100 \mathrm{~km}$.

Consistent with this modest estimated amount of total slip transferred is the lack of clear offset of the most obvious morphologic feature of the Taiwan subduction/collision system: the steep eastern topographic slope of the Central Mountains, which extends relatively smoothly southward to the steep eastern bathymetric slope of the submarine accretionary prism (Fig. 3). If these apparently related features are linked across the region off southernmost Taiwan, where a steep slope is absent, the overall pattern is not one of an offset feature, but a rather sharply kinked lineament. The eastern mountain slope on the island trends about $\mathrm{N} 20^{\circ} \mathrm{E}$, as far south as the southern end of the Longitudinal Valley, where the extension of this feature turns due south. Intriguingly, the discrepancy in orientation is quite similar to the paleomagnetically defined clockwise rotation of the accreted arc rocks of the Coastal Range (Lee et al., 1991). The arc appears to be conforming to the shape of the Asian margin, deforming internally as it is welded to the continent.

\section{Timing of arc accretion}

Based on local plate convergence of $86 \mathrm{~mm} / \mathrm{yr}$ (Yu and Chen, 1994) and the geometry of the plate boundary, the collision is propagating southward at about $100 \mathrm{~km} / \mathrm{m}$.y. (Fig. Ib; see Suppe, 1984). In terms of development of the collision, moving 100 $\mathrm{km}$ south along the collision is equivalent to moving I m.y. back in time. This space-time equivalency has provided a powerful analytical tool for the study of the Taiwan collision: applying it to the largescale morphology of the accretionary prism south of Taiwan suggests that the submarine tip of the propagating collision extends about $170 \mathrm{~km}$ south of the Hengchun Peninsula, and so represents the most recent 1.7 million years or so of propagation of the collision. A more specific corollary to this relationship suggests that in the transitional region of nascent collision immediately south of Taiwan, collisional processes should lag behind those seen onland by about the same rate. Thus the along-strike collisional segment characterized by formation and uplift of the Huatung Ridge should be experiencing collisional processes and tectonic events about 1 m.y. after these processes and events have affected the segment represented by the onland Coastal Range.

Comparison of geochronologic relationships onland in eastern Taiwan with the offshore region immediately to the south suggests that this diachronous relationship is generally true. Marine sedimentation in the stratigraphic sections exposed in the Coastal Range generally continued through much of the Pliocene to about $0.9 \mathrm{Ma}$, or to as recently as 0.5 Ma locally (Chi et al., 1981; Lundberg and Dorsey. 1988. 1990; Huang et al.. 1992). In the region of the Huatung Ridge, active sedimentation is clearly still active, but it is likely that sedimentation rates in the present basins have decreased relatively recently as basins have filled and experienced deformation and uplift. The Southern Longitudinal Trough is essentially full to the depth of the sill formed by the Huatung Ridge. Most sediment input to this basin is transported across the basin to the Taitung Trough, and thence to the Philippine Sea (backarc region). Lowered sedimentation rates at present should translate to dramatically reduced long-term preservation potential of the younger part of the detrital record here if these regions are subsequently uplifted during continued collision. with the youngest deposits that form the upper one kilometer or so extremely susceptible to erosion upon subaerial emergence (Lundberg and Dorsey, 1990).

Basinal areas between the accreting are and the accretionary prism that are capable of retaining thick orogenic sequences are restricted to latitudes south 
of about $22^{\circ} 05^{\prime} \mathrm{N}$, or about $80 \mathrm{~km}$ south of the southern extent of the Coastal Range. This distance corresponds to a time equivalence on the order of about 1 m.y. of collision propagation. The major depocenter of the forearc region, the North Luzon Trough, extends northward only as far as about $21^{\circ} 20^{\prime} \mathrm{N}$, about $155 \mathrm{~km}$ south of the Coastal Range, corresponding to a time equivalence of about 1.5 m.y. of propagation.

The youngest significant igneous activity documented by dating of volcanic rocks of the accreted arc terrane in the Coastal Range dates to about 2.2 $\mathrm{Ma}$, whereas the youngest volcanism in the offshore region, represented by Hsiaolanhsu island, is about 0.02 Ma (Yang, 1995). Uplift of at least some portions of the Coastal Range appears to have been accomplished in somewhat less than $1 \mathrm{~m} . \mathrm{y}$. (Lundberg and Dorsey, 1990). Uplift of the analogous domain to the south has begun with uplift of the Huatung Ridge. The main arc massif to the south of eastern Taiwan has not yet experienced wholescale uplift at present, judging from both overall bathymetry and from the lack of uplifted associated deep-water deposits. However, uplift of the northernmost islands is rapid at present, on the order of $6 \mathrm{~mm} / \mathrm{yr}$ (Wang and Burnett, 1990). If this uplift continues at the present rate, some arc rocks of the transition zone will experience total uplift of about $6 \mathrm{~km}$ over 1 m.y., approximately equal to the maximum uplift documented in the onland sequences.

\section{Conclusions}

(1) The submarine accretionary prism south of Taiwan grows arcward through the region of initial collision by backthrusting, deforming and incorporating strata of the forearc basin and subsidiary collisional basins within its arcward flank.

(2) Along the submarine region through which the collision actually develops, which comprises a transition zone between normal subduction and collision, the Huatung Ridge has been formed by this backthrusting along the rear of the accretionary prism. The Huatung Ridge is a structural and bathymetric high that morphologically branches off from the main accretionary prism, and separates to become a distinct ridge, parallel to but about $30 \mathrm{~km}$ arcward of the main prism.
(3) The Taitung Trough, a complex linear depression including segments of steep, narrow submarine canyons and deep basinal areas, is formed along the deformation front of the Huatung Ridge, comprising the eastern boundary of the collision complex at the stage of the collision represented by the area just south of eastern Taiwan. Deformed strata of the Huatung Ridge, which form the western slope of the Taitung Trough, are being thrust eastward over the western flank of the Luzon arc, likely incorporating arc rocks in the deformation, by analogy with rocks exposed onland immediately to the north.

(4) The Huatung Ridge serves to dam orogenic sediment in an elongate N-S basin, the Southern Longitudinal Trough. This suture basin is presently full to the depth of its structural sill, allowing bypass of orogenic sediment eastward to the Taitung Trough and thence to the backarc region of the Philippine Sea.

(5) Comparison of marine geophysical data in the offshore region through which the Luzon arc is actively becoming incorporated into the collision complex with results of land-based investigations along the suture exposed in eastern Taiwan suggests a relatively systematic progression of processes and events, as the collision evolves through time and space. An apparently recent feature is the arcward transfer of more than half of the total plate convergence in this system, to the region between the southern Central Mountains and the northernmost islands of the Luzon arc offshore.

(6) The arcward flank of the collision evolves in a complicated fashion. The frontal (trenchward) portion of the prism appears to evolve relatively systematically, growing with successive accretion of the thick incoming passive-margin sequence to become an emergent foreland fold and thrust belt (Reed et al., 1992). The collision boundary on the arcward flank of the system, in contrast, varies dramatically along strike (Lundberg et al., 1992). Structurally, the vergence of thrust systems apparently flips at about the onland/offshore boundary, and along-strike changes in thrust geometry serve to separate and define sedimentary basins of quite distinct character. The combination of along-strike variations in structural geometry with pre-existing topographic variations along the volcanic arc likewise serves to effectively dam and direct sediment input from the 
rapidly eroding collisional orogen to the north, filling some basins to their sill depth and cutting off sediment supply to others.

\section{Acknowledgements}

We thank the captain and crew of the R/V Moana Wave and A.N. Shor and technical staff of the Hawaii Institute of Geophysics for their help in data acquisition, and Karen Sender for reprocessing of SeaMARC II data. Stephen Lewis and Chi-Yue Huang provided helpful reviews. This study presents part of the results from a joint research project and was supported by the National Science Foundation (OCE$8911507)$ and the National Science Council, Republic of China (NSC79-0209-M002A-14 and NSC800202-M-002A-01 to C.S. Liu).

\section{References}

Bonilla, M.G., 1975. A review of recently active faults in Taiwan. U.S. Geol. Surv., Open-file Rep., 75-41, 58 pp.

Chen, M.-P., Shieh, Y.-T. and Shyr, C.-S., 1992. Seatloor physiography and surface sediments off southeastern Taiwan. Acti Geol. Taiwan., 26: 333-353.

Chi, W.R.. Namson. J. and Suppe, J., 1981. Stratigraphic record of plate interactions in the Coastal Range of eastern Taiwan. Geol. Soc. China Mem., 4: 491-530

Crespi, J.M.. Chan, Y.-C. and Swaim, M.S., 1996. Synorogenic extension and exhumation of the Taiwan hinterland. Geology. 24: $247-250$.

Dorsey, R.J., 1988. Provenance evolution and unroofing history of a modern arc-continent collision: Evidence from petrography of Plio-Pleistocene sandstones, eastern Taiwan. J. Sediment. Petrol., 58: 208-218.

Fuh et al., 1997. Strike-slip faults offshore southern taiwan: Implications for the oblique arc-continent collision processes. In: S.E. Lallemand and H.-H. Tsien (Editors), Active Collision in Taiwan. Tectonophysics, 274: 25-39.

Hsu, T.L.. 1962. Recent faulting in the Longitudinal Valley of eastern Taiwan. Geol. Soc. China Mem., 1: 95-102.

Huang, C.Y., Chyu, C.-T., Lin, S.B., Lee, T.Q. and Sheu, D.D.. 1992. Marine geology in the arc-continent collision zone off southeastern Taiwan: implications for Late Neogene evolution of the Coastal Range. Mar. Geol., 107: 183-212.

Lee, T.Q.. Kissel, C., Barrier, E., Laj, C. and Chi, W.R. 1991. Paleomagnetic evidence for a diachronic clockwise rotation of the Coastal Range, eastern Taiwan. Earth Planet. Sci. Lett. 104: 245-257.

Lewis, S.D. and Hayes, D.E., 1984. A geophysical study of the Manila Trench, Luzon. Philippines, 2. Foreare basin structural and stratigraphic evolution. J. Geophys. Res., 89: 91969214.

Lewis, S.D. and Hayes, D.E.. 1989. Plate convergence and defor- mation. North Luzon Ridge, Philippines. Tectonophysics, 168 : 221-237.

Lieske. J., Jr., Lundberg, N. and Reed, D.L., 1992. Backthrusting and accretion in the submarine Taiwan accretionary prism: SeaMARC II and seismic reflection data. EOS, Trans. Am. Geophys. Union, 73: 557.

Liu, C.C. and Yu, S.B., 1990. Vertical crustal movements in eastern Taiwan and its tectonic implications. Tectonophysics. 183: $111-119$.

Lo. C.H., Onstott, T.C., Chen, C.-H. and Lee, T., 1994. An alssessment of ${ }^{40} \mathrm{Ar} /{ }^{39} \mathrm{Ar}$ dating for the whole-rock volcanic samples from the Luzon Arc near Taiwan. Chem. Geol., 114 : 157-178.

Lundberg. N., 1988. Present-day sediment transport paths south of the Longitudinal Valley, southeastern Taiwan. Acta Geol. Taiwan.. 26: 317-331.

Lundberg, N. and Dorsey. R.J., 1988. Synorogenic subsidence and sedimentation in a Plio-Pleistocene collisional basin, eastern Taiwan. In: K.L. Kleinspehn and C. Paola (Editors), New Perspectives in Basin Analysis. Springer-Verlag, New York. pp. 265-280.

Lundberg, N. and Dorsey, R.J., 1990. Rapid Quaternary emergence, uplift, and denudation of the Coastal Range, eastern Taiwan. Geology, 18: 638-641.

Lundberg, N.. Reed, D.L., Liu, C.S. and Lieske, J., 1992. Structural controls on orogenic sedimentation, submarine Taiwan collision. Acta Geol. Taiwan., 30: 131-140.

Page, B.M. and Suppe, J., 1981. The Pliocene Lichi Melange in Taiwan: its plate tectonic and olistostromal origin. Am. J. Sci.. 281: 193-227.

Pezzopane. S.K. and Wesnousky, S.G.. 1989. Large earthquakes and crustal deformation near Taiwan. J. Geophys. Res., 94: $7250-7264$.

Rau. R.-J. and Wu, F.T., 1995. Tomographic imaging of lithospheric structures under Taiwan. Earth Planet. Sci. Lett., 1.33: $517-532$.

Reed. D.L... Lundberg, N., Liu, C..S. and Kuo, B.-Y.. 1992. Structural relations along the margins of the offshore Taiwan iccretionary wedge: implications for accretion and crustal kinematics. Acta Geol. Taiwan., 30: 105-122.

Roecker, S.W., Yeh, Y.H. and Tsai, Y.B., 1987. Three-dimensional $P$ and $S$ wave velocity structures beneath Taiwan: deep structure of an arc-continent collision. J. Geophys. Res., 92: $10.547-10.570$.

Seno, T. Stein, S. and Gripp, A.E., 1993. A model for the motion of the Philippine Sea plate consistent with NUVEL-1 and geological data. J. Geophys. Res., 98: 17,941-17,948.

Suppe, J., 1981. Mechanics of mountain building in Taiwan. Geol. Soc. China, Mem., 4: 67-89.

Suppe. J., 1984. Kinematics of arc-continent collision, flipping of subduction, and back-arc spreading near Taiwan. Geol. Soc. China Mem., 6: 21-33

Suppe, J.. 1987. The active Taiwan mountain belt. In: J.-P. Schaer and J. Rodgers (Editors), The Anatomy of Mountain Ranges. Princeton University Press, Princeton, N.J., pp. 277-293.

Wang, C.H. and Burnett, W.C., 1990. Holocene mean uplift rates across an active plate-collision boundary in Taiwan. Science. 
248: 204-206.

Wu, F.T., Chen, K.-C., Wang, J.-H, McCaffrey, R. and Salzberg, D., 1989. Focal mechanisms of recent large earthquakes and the nature of faulting in the Longitudinal Valley of eastern Taiwan. Proc. Geol. Soc. China, 32: 157-177.

Yang, T.F., 1995. Fission-track dating of volcanics in the northern part of the Taiwan-Luzon Arc: eruption ages and evidence for crustal contamination. J. Southeast As. Earth Sci., 11(2): 81-93.
Yu, S.-B. and Chen, H.-Y., 1994. Global Positional System measurements of crustal deformation in the Taiwan arc-continent collision zone. Terrestr. Atmos. Oceanic Sci., 5: 477-498.

Yu, S.-B. and Liu, C.-C., 1989. Fault creep on the central segment of the Longitudinal Valley fault, eastern Taiwan. Proc. Geol. Soc. China, 32: 209-231.

Yu, S.-B., Kuo, L.-C. and Lee, C., 1992. Crustal deformation in the southern Longitudinal Valley area, eastern Taiwan. J. Geol. Soc. China, 35: 219-230. 